\title{
Albertus Magnus en het begrip ‘een’
}

Citation for published version (APA):

Remmé, J. H. M. (2015). Albertus Magnus en het begrip 'een'. [, Maastricht University]. Maastricht University. https://doi.org/10.26481/dis.20151126jr

Document status and date:

Published: 01/01/2015

DOI:

10.26481/dis.20151126jr

Document Version:

Publisher's PDF, also known as Version of record

\section{Please check the document version of this publication:}

- A submitted manuscript is the version of the article upon submission and before peer-review. There can be important differences between the submitted version and the official published version of record.

People interested in the research are advised to contact the author for the final version of the publication, or visit the DOI to the publisher's website.

- The final author version and the galley proof are versions of the publication after peer review.

- The final published version features the final layout of the paper including the volume, issue and page numbers.

Link to publication

\footnotetext{
General rights rights.

- You may freely distribute the URL identifying the publication in the public portal. please follow below link for the End User Agreement:

www.umlib.nl/taverne-license

Take down policy

If you believe that this document breaches copyright please contact us at:

repository@maastrichtuniversity.nl

providing details and we will investigate your claim.
}

Copyright and moral rights for the publications made accessible in the public portal are retained by the authors and/or other copyright owners and it is a condition of accessing publications that users recognise and abide by the legal requirements associated with these

- Users may download and print one copy of any publication from the public portal for the purpose of private study or research.

- You may not further distribute the material or use it for any profit-making activity or commercial gain

If the publication is distributed under the terms of Article $25 \mathrm{fa}$ of the Dutch Copyright Act, indicated by the "Taverne" license above, 


\section{ALBERTUS MAGNUS EN HET BEGRIP 'EEN'}

\section{J. H. M. Remmé}

Stellingen

4 stellingen over het onderwerp van het proefschrift

- Albertus bouwt met zijn eigen definitie van 'een' als “ongedeeld in zichzelf en gedeeld (apart gezet) van andere dingen" voort op het denken van Aristoteles, maar legt het accent op "afbakenen" in plaats van op de ondeelbaarheid van het zijnde en voegt verder het Neo-Platoonse element van "relatie tot het eerste beginsel" aan de Aristotelische definitie toe.

- Albertus' theorie van een dubbele akt van de forma, waarmee de totstandkoming van het zijnde vanuit de akten van 'zijnde' en 'een' wordt aangegeven, vormt een voorbeeld van een hem kenmerkende lijn van denken.

- Uit de thematisering van het begrip 'een' bij Albertus blijkt dat Albertus de denkbeelden van Avicenna en Averroës introduceerde bij zijn tijdgenoten, terwijl hij tegenover beiden, en dan vooral tegenover Averroës, een kritische uiteenzetting ontwikkelde.

- Het oude beeld als zou Albertus slechts een "récitateur" van de denkbeelden van anderen zijn geweest moet sterk worden bijgesteld.

3 over vakgebied, niet proefschrift.

- De studie van de antieke en middeleeuwse wijsbegeerte verdient herwaardering in het licht van nieuwe inzichten.

- De aandacht voor historische wijsbegeerte maakt het mogelijk om te reflecteren op het moderne denken.

- De Libera heeft in zijn geschriften laten blijken hoezeer het middeleeuwse denken onderdeel uitmaakt van een ononderbroken "philosophia perennis".

1 over valorisatie

- Het onderzoek zal significant bijdragen aan kennis over de invloed van de middeleeuwse (incl. Islamitische) filosofie, vooral de Metaphysica, op de ontwikkeling van de wetenschap in Europa.

Overig

- De Johnny Cash' ballade "One" gaat meer over de eenzaamheid van de onderzoeker dan over het door hem onderzochte thema.

- Johann Sebastian Bach zocht in getallen toegang tot het hogere, wat als een Neoplatoons element in zijn levenshouding kan worden aangemerkt. 